\title{
Remote Sensing Technology: Vegetation Index Analysis Based On Landuse
}

\author{
Dasrizal $^{1}$, Rahmi $^{2}$, A Rezki $^{3}$, A Z P Ulni ${ }^{4}$, Farida $^{5}$ \\ $1,2,3,4,5$ STKIP PGRI Sumatera Barat, Geography Education Department, Indonesia \\ \{dasrizal204@gmail.com¹, rahmi_65@yahoo.com², afrital.rezki@gmail.com³,ariezella@gmail.com4, \\ aifarida@yahoo.com $\left.{ }^{5}\right\}$
}

\begin{abstract}
This study aims to determine: 1) Land use classification in 2016 in Solok Regency, 2) vegetation density (NDVI) and 3) vegetation density (NDVI) in the research area. The data used in this research is the density data of vegetation and the area that is taken from the Landsat 8 OLI image in 2016. The method used in this study is Landsat 8 OLI image interpretation by calculating the index of vegetation density or Normalized Difference Vegetation Index (NDVI) obtained by the calculation of near infrared with red reflected by the plant. The NDVI value is obtained by comparing near-infrared (NIR) and Red data. NDVI is the value of Normalized Difference Vegetation Index, NIR is band 5 and Red is from band 4 in Landsat image 8. Technique of analysis using Geography Information System (GIS), by determining value of vegetation canopy density using the result from NDVI calculation, then the NDVI class values are reclassified into three classes, which are rare, medium and tight density. The results showed: In 2016 identified there are as many as 9 types of land use. The land uses are Primary Forest, Secondary Forest, Paddy Field, Settlements, Mixed Plantations, Crop Fields, Water Bodies, Bushes, and Plantations. The most widespread use is Primary Forest. The level of vegetation density in Solok Regency ranges from rare, medium, and tight density levels. Water Bodies have an area of 6,690 ha (1.98\%), vegetation having a rare density of 79,208 ha (23.49\%), vegetation with a medium density of $77,098(22.86 \%)$, and for density the meeting has an area of 174,223 ha $(51.66 \%)$.
\end{abstract}

Keyword: NDVI, Landuse, Remote Sensing, Landsat 8 OLI

\section{INTRODUCTION}

Increased concentrations of greenhouse gases (GHGs) resulting in an increase in Earth's surface temperature and climate change is one of the global environmental problems [1] [2] [3]. Based on the World Bank's report in 2012 that if the citizens of the earth do nothing (Bussiness As Usual) in order to reduce the rate of GHG concentration will be an increase in earth surface temperature of $4{ }^{\circ} \mathrm{C}$ [4] [5]. The main source of GHG emissions in Indonesia comes from the forestry sector due to deforestation. Based on the GHG inventory conducted by the Ministry of Environment in 2009 that the GHG emissions from deforestation in 2000-2005 amounted to $1,089,000$ hectares per year. The amount of emissions from peat fires amounts to 172,000 million tonnes of CO2-eq in 2000 or $12 \%$ of Indonesia's total emissions[6]. 
The GHG emissions of West Sumatera Province come from three areas: 1) Agriculture and forestry (land-based), 2) Energy, transportation and industry (energy based) and 3) Waste management with total emissions of about 106 million tons $\mathrm{CO}_{2}$-eq in 2010. The projection result using BAU scenario of West Sumatera Province in 2020 will contribute $96.4 \%$ of GHG emissions from land-based [7]. The Regional Action Plan for GHG Emission Reduction in West Sumatera Province has been prepared based on action plans for land-based group mitigation, energy and waste management[8].

Biomass is highly relevant to climate change issues and plays an important role in the carbon cycle [9]. Biomass estimation can be done with three approaches namely modeling, direct measurement in field and Remote Sensing [10][11]. Of the three approaches, the approach with Remote Sensing is preferred because it can be used for large areas[12]. One of the utilization of remote sensing technology is through Landsat image. The estimation of biomass through Landsat Imagery is done by vegetation index approach [10].

The vegetation index is one of the parameters used to analyze the vegetation state of a region. The index has a variety of algorithmic variations [13]. A number of NDVI reductions and alternatives have been proposed by a number of researchers to refine these parameter deficiencies, such as the Perpendicular Vegetation Index (PVI), the Atmospherically Resistant Vegetation Index (ARVI) and the Global Environment Monitoring Index (GEMI), the Enhanced Vegetation Index (EVI) [14]. As the name implies, each index is calculated by including a correction factor on one or more of the factors that are NDVI deficient [15][16].

Identification NDVI used Landsat 8 OLI imagery [17]. The Landsat 8 satellite has Onboard Operational Land Imager (OLI) and Thermal Infrared Sensor (TIRS) sensors with 11 channels. Among the canals, 9 channels (bands 1-9) are in OLI and 2 others (bands 10 and 11) on the TIRS. Most canals have similar specifications to Landsat 7. The vegetation index is a mathematical combination between bend red and NIR bends that have long been used to identify the presence and condition of vegetation [18].

\section{RESEARCH METHOD}

The research location was conducted in Solok Regency, West Sumatera Province, Indonesia. Geographically, Solok regency lies between $00^{\circ} 32$ ' $14^{\prime}$ ' and $01^{\circ} 466^{\prime} 45$ "South Latitude and

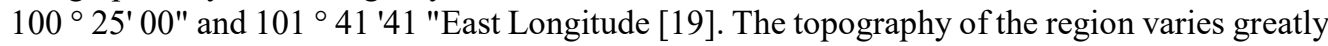
between plains, valleys and hills, with altitudes between 329 meters - 1458 meters above sea level [20]. The method in this research is Quantitative descriptive, locate in Solok regency, remote sensing visual/digital image interpretation, and fieldwork. The materials used in this research are:

a. LANDSAT 8 OLI Image (Solok Regency, $30 \mathrm{~m}$ resolution, recording in 2016) to create a mapping unit and field checkpoint determination, LANDSAT 8 OLI image is used because

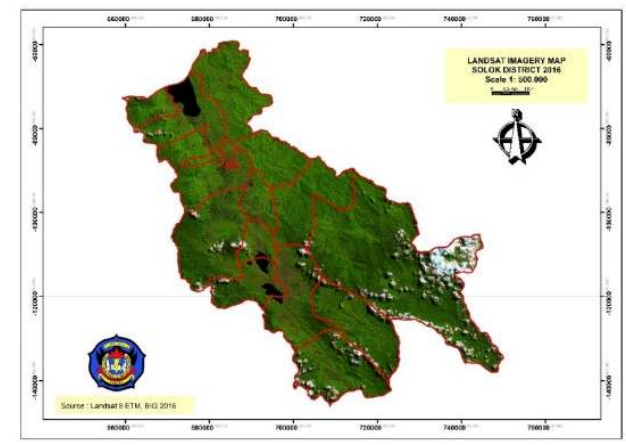


it has the better spectral resolution to display landuse. Landsat $8 \mathrm{OLI}$ image is presented in Figure1:

Figure1. Solok Regency Landsat 8 OLI Images

b. Topographic maps scale 1: 50.000 include Solok Regency (Bakosurtanal, 2006).

Image Geometric Correction

The Landsat 8 OLI image used in this study has not undergone any geometric correction so geometric correction is required by using image to image by using geometrically corrected LANDSAT 7 ETM + image.

Image Processing

Data processing in this research includes Masking (image cutting), visual image interpretation (Vegetation Type and Land Characteristic) and digitally (Density Heading using NDVI vegetation index transformation):

1. Masking (cutting image)

Masking process is done to separate the research area, in this case Solok Regency[21].

2. Preparation of land use maps

Land use maps are used as an approach in determining the checkpoint of the field. Three approaches to land use are used: vegetation type, land characteristics [22], and vegetation density. Type of vegetation, the different types of vegetation seen in image recording represent different types of vegetation, different types of vegetation will produce different biomass, this is because the difference in volume density between each species is different [23]. In this process different features are assumed to have different types of constituent vegetation, different types are assumed to be different types of vegetation.

Interpretation of vegetation density, the more density vegetation carbon content will be greater [24]. The rate of photosynthesis in closer vegetation areas is also higher so that the rate of $\mathrm{CO} 2$ changes becomes faster biomass in areas with more dense vegetation. Determination of vegetation density by using the index value of NDVI transformation, NDVI transformation has a range of values between $(-1)$ to $(+1)$. Index values smaller or equal to 0 indicate clouds, water and other coverings other than vegetation. Values representing vegetation are in the range 0.2 to 0.7 and above these values illustrate the health level of vegetation cover.

c. Vegetation index

Digital image processing in LANDSAT image after radiometric and geometric correction is transformed Vegetation Index, where the value obtained is a combination of spectral band specific from image to highlight the appearance of vegetation. The Vegetation Index is a greenness measurement of the vegetation canopy, the composite properties of leaf chlorophyll, leaf area, vegetation canopy structure and cover [25]. The NDVI value is obtained by the calculation of Near Infrared with Red reflected by the plant. The NDVI value is obtained by comparing the data of Near Infrared and Red [26]. with the following formula:

(NIR-Red)

NDVI $=$

(NIR+Red)

From the equation number 1, NDVI is the value of Normalized Difference Vegetation Index, NIR is band 5 Image of Landsat 8 OLI and Red is band 4 of Landsat image 8 OLI [22]. To determine the value of vegetation canopy density using result from NDVI calculation, then the value of NDVI class is reclassified into three classes, low density, medium density and high density[11][24]. 


\section{RESULTS AND DISCUSSION}

Based on the results of remote sensing data analysis with GIS obtained the following results: In 2016 identified there are 9 types of land use. The land uses are Primary Forest, Secondary Forest, Paddy Field, Settlement, Mixed Plantations, Crop Fields, Water Bodies, Bushes, and Plantations. The following table will explain the area of each land use. Presented in Table 1:

\begin{tabular}{clrr}
\multicolumn{4}{c}{ Table 1. Landuse Area in Districk Solok Regency } \\
\hline No & \multicolumn{1}{c}{ Landuse } & Area (ha) & \multicolumn{1}{c}{ \% } \\
\hline 1 & Primary Forest & 159,544 & 47.31 \\
2 & Secondary Forest & 14,679 & 4.35 \\
3 & Paddy Field & 45,591 & 13.52 \\
4 & Settlement & 3,963 & 1.18 \\
5 & Mixed Plantations & 76,478 & 22.68 \\
6 & Crop Fields & 27,489 & 8.15 \\
7 & Water Bodies & 6,690 & 1.98 \\
8 & Bushes & 2,165 & 0.64 \\
9 & Plantations & 620 & 0.18 \\
\hline \multicolumn{4}{c}{ Total }
\end{tabular}

Source: Data analysis, 2017

Seen in 2016, most land use is the Primary Forest area of $159.544 \mathrm{Ha}(47.31 \%)$, then Mixed Plantations with 76.478 ha $(22.68 \%)$. The third largest landuse is paddy fields, rice field is land use cultivation which also brings the most income to Solok Regency. Solok Regency is famous for its rice production. This regency is always self-sufficient in rice every year. Rice production averages 4.7 tons per hectare. This large rice production is then distributed to meet the needs of rice in West Sumatra Province. People in West Sumatra Province are people who make rice as their staple food. This makes Solok District one of the districts that support food sources in West Sumatra. The land use of Solok Regency in 2016 for each type of land use can be seen in the following Figure 2:

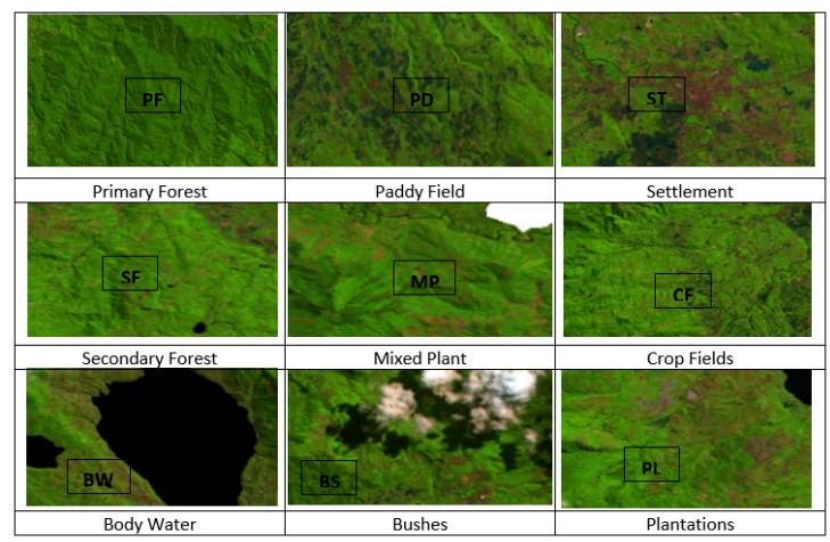

Distribution of each type of land use in Solok Regency in 2016 still forms a typical pattern of land use types of Regency (rural) areas where the highest percentage of land use is forest land and another agricultural land. Desa or Nagari is the smallest administrative area in Indonesia. 
Desa is an area that has certain characteristics. Based on the pattern, the village has the characteristics of a more traditional place, generally, the population has a livelihood that is directly related to nature. This was also seen in Solok Regency when field checks were carried out, the land use model characterized rural areas. Based on the results of remote sensing analysis and field cheks, land use for agricultural cultivation has a large area. In addition to rice fields, in Solok Regency, the landuse like a Mixed Plant, Crop Fields and Plantations. In Mixed Plant landuse the most planted crops such as rubber and coffee, in crop fields land use was planted with corn and vegetables. In the Plantations, planted with tea plants. Tea in Solok Regency, in the Alahan Panjang area, is a fairly extensive state-owned plantation. Then, for dry land in Solok Regency, it is generally processed and developed as land fisheries such as ponds, ponds and irrigation channels to irrigate paddy fields. While some other landuses are bushes, the landuse cattle pens and grasslands for animal feed such as cattle and buffaloes. In addition to land use related to agricultural and economic activities, some rural land in Solok Regency is also used for public facilities such as places of worship, graves, schools, village offices and health facilities such as health centers. The distribution of land use of Solok Regency in 2016 can be seen in the following map. Figure 3:

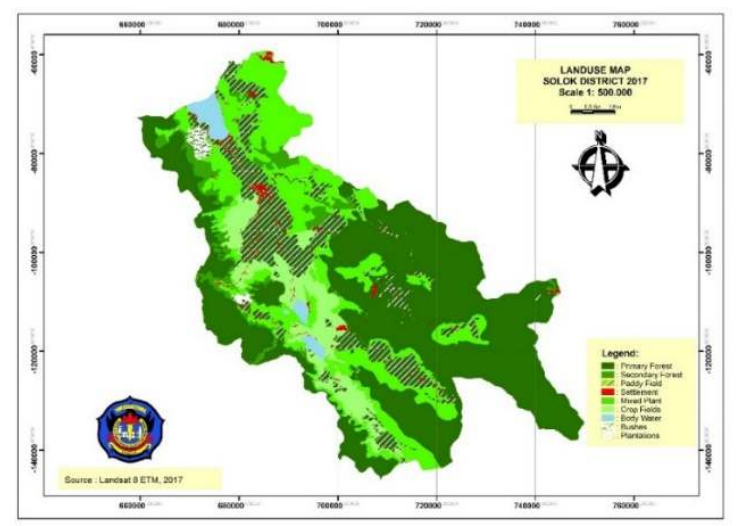

Figure. 3. Solok Regency Landuse Map

Based on data analysis with GIS, the yield of vegetation density in Solok Regency ranged from the density of rare, medium, and meeting. Water Bodies have an area of 6,690 ha (1.98\%), vegetation having a rare density of 79,208 ha $(23.49 \%)$, vegetation with a medium density of $77,098(22.86 \%)$, and for density the meeting has an area of 174,223 ha (51.66\%). Based on the calculation of Normalized Difference Vegetation Index (NDVI) can be seen briefly in Table 2:

Table 2. NDVI Value base on Landuse in Solok Regency

\begin{tabular}{cccc}
\hline No & NDVI value & Class & $(\mathrm{Ha})$ \\
\hline 1 & $-0,232-0,022$ & Water Bodies & 6.690 \\
2 & $0,022-0,188$ & Low density & 79.208 \\
3 & $0,188-0,398$ & Medium Density & 77.098 \\
\hline 4 & $0,398-0,593$ & Hight Density & 174.223 \\
\hline \multicolumn{4}{c}{ Source: }
\end{tabular}

Source: Data analysis, 2017

Based on the results of data processing from 8 OLI Landsat about the level of vegetation density in Solok Regency known that landuse dominated by the green color of primary forest and secondary forest. Reclassification process with geographic information system obtained 
three classes of vegetation density level. Areas with vegetation are rarely indicated by light purple, the color indicates that the area has little vegetation with a vegetation density index of $0.022-0.188$. Areas with medium density vegetation are indicated by light green color, with a vegetation density index of $0.188-0.398$. Areas that have dense vegetation density levels are shown in dark green, with density indexes ranging from 0.398 to 0.593 . The old greenishness shows that the area still has a lot of vegetation. The vegetation index itself actually describes the greenishness of the plant. This index is a mathematical combination between the red band (Red) and NIR (Near Infrared Radiation). Blue color indicates that the object is a body of water and clouds with an index value of $-0.232-0.022$.

When viewed from the appearance of the image, the area with the vegetation density is rarely characterized by light colors, this is due to the reflection of the small vegetation canopy, so the impression that appears in the image is brighter. Conversely, areas with dense vegetation density levels are indicated by darker / greener color because the reflection of the vegetation canopy is high.

\section{CONCLUSION}

Based on the result of research, it can be concluded that: (1) in 2016 identified there are 9 types of land use. The land uses are Primary Forest, Secondary Forest, Paddy Field, Settlements, Mixed Plantations, Crop Fields, Water Bodies, Bushes, and Plantations. The most widespread use is Primary Forest (2) the level of vegetation density in Solok Regency ranges from rare, medium, and tight density levels. Water Bodies have an area of 6,690 ha (1.98\%), vegetation having a rare density of 79,208 ha $(23.49 \%)$, vegetation with a medium density of 77,098 $(22.86 \%)$, and for density the meeting has an area of 174,223 ha $(51.66 \%)$.

\section{ACKNOWLEDGEMENTS}

The author would like to thank Kementerian Riset Teknologi dan Pendidikan Tinggi for providing us the research funding through grand scheme of Penelitan Produk Terapan 2018/2019. Our highly appreciation for United States Agency for International Development (USAID) for the training and mentoring support in writing this article, through the Sustainable Higher Education Research Alliance (SHERA) Program for Universitas Indonesia's Scientific Modeling, Application, Research and Training for City-centered Innovation and Technology (SMART CITY) Project.

\section{REFERENCES}

[1] B. A. Linquist et al., "Reducing greenhouse gas emissions, water use, and grain arsenic levels in rice systems," Glob. Chang. Biol., vol. 21, no. 1, pp. 407-417, 2015.

[2] H. K. Gibbs, S. Brown, J. O. Niles, and J. A. Foley, "Monitoring and estimating tropical forest carbon stocks: Making REDD a reality," Environ. Res. Lett., vol. 2, no. 4, 2007.

[3] Editorial Essay, "Kyoto Protocol: The Unfinished Agenda." Climatic Change, pp. 1-21, 1998.

[4] J. Sterman, T. Fiddaman, T. Franck, and A. Jones, "World Climate: A Role-Play Simulation of Global Climate Negotiations," MIT Sloan Sch. Manag. Work. Pap., pp. 141, 2003.

[5] G. Vaglio et al., "ISPRS Journal of Photogrammetry and Remote Sensing Above ground biomass estimation in an African tropical forest with lidar and hyperspectral data," ISPRS 
J. Photogramm. Remote Sens., vol. 89, pp. 49-58, 2014.

[6] G. R. Van Der Werf, J. T. Randerson, L. Giglio, N. Gobron, and A. J. Dolman, "Climate controls on the variability of fires in the tropics and subtropics," Global Biogeochem. Cycles, vol. 22, no. 3, pp. 1-13, 2008.

[7] Masganti, Wahyunto, A. Dariah, Nurhayati, and R. Yusuf, "Karakteristik dan Potensi Pemanfaatan Lahan Gambut Terdegradasi di Provinsi Riau," J. Sumberd. Lahan, vol. 8, no. 1, pp. 59-66, 2014.

[8] R. Djalante and F. Thomalla, "Disaster risk reduction and climate change adaptation in Indonesia: Institutional challenges and opportunities for integration,” Int. J. Disaster Resil. Built Environ., vol. 3, no. 2, pp. 166-180, 2012.

[9] E. F. Suebu, J. Hermana, and R. Boedisantoso, "Mitigation strategy on reduction greenhouse gas (GHG) emission of landuse sector for the province of Papua," Sustinere J. Environ. Sustain., vol. 1, no. 2, pp. 109-117, 2018.

[10] D. Lu, "The potential and challenge of remote sensing-based biomass estimation," Int. J. Remote Sens., vol. 27, no. 7, pp. 1297-1328, 2006.

[11] D. Zheng et al., "Estimating aboveground biomass using Landsat 7 ETM+ data across a managed landscape in northern Wisconsin, USA," Remote Sens. Environ., vol. 93, no. 3, pp. 402-411, 2004.

[12] M. A. Wulder et al., "Landsat continuity: Issues and opportunities for land cover monitoring," Remote Sens. Environ., vol. 112, no. 3, pp. 955-969, 2008.

[13] X. Zhu and D. Liu, "Improving forest aboveground biomass estimation using seasonal Landsat NDVI time-series," ISPRS J. Photogramm. Remote Sens., vol. 102, pp. 222-231, 2015.

[14] S. Eckert, F. Hüsler, H. Liniger, and E. Hodel, "Trend analysis of MODIS NDVI time series for detecting land degradation and regeneration in Mongolia," J. Arid Environ., vol. 113, pp. 16-28, 2015.

[15] G. T. Yengoh, D. Dent, L. Olsson, A. E. Tengberg, and C. J. Tucker, "The use of the Normalized Difference Vegetation Index (NDVI) to assess land degradation at multiple scales: a review of the current status, future trends, and practical considerations," Lund Univ. Cent. Sustain. Stud. (LUCSUS), Sci. Tech. Advis. Panel Glob. Environ. Facil., p. 47, 2014.

[16] Y. R. Lai, M. J. Pringle, P. M. Kopittke, N. W. Menzies, T. G. Orton, and Y. P. Dang, "An empirical model for prediction of wheat yield, using time-integrated Landsat NDVI," Int. J. Appl. Earth Obs. Geoinf., vol. 72, no. January, pp. 99-108, 2018.

[17] D. D. Huedvlv et al., "Kajian Perubahan Penggunaan Lahan Berbasis Citra Penginderaan Jauh Resolusi Menengah dengan Metode Multi Layer Perceptron dan Marcov Chain di Sebagian Kabupaten Bantul," in Prosiding Pertemuan Ilmiah Tahunan XX 2015, 2015, pp. 198-205.

[18] Lillesand T.M. and R.W.Kiefer, Penginderaan Jauh dan Interpretasi Citra, 3rd ed. Yogyakarta: Gadjah Mada University Press, 1997.

[19] A. Y. Nofrizal, F. Walad, E. S. Permana, S. Anwar, and Y. Antomi, "Identifikasi Perubahan Penggunaan Lahan di Kota Solok, Sumatera Barat Berbasis Penginderaan Jauh dan SIG dengan menggunakan Object Base Image Analyst ( OBIA ),” 2018, pp. 96-104.

[20] J. (STIE E. H. Badri, "Analisis Potensi dan Pertumbuhan Ekonomi Daerah Kabupaten Solok," Sos. dan Hum., vol. 1, no. 2, 2015.

[21] J. E. Luther, R. A. Fournier, D. E. Piercey, L. Guindon, and R. J. Hall, "Biomass mapping using forest type and structure derived from Landsat TM imagery," Int. J. Appl. Earth Obs. Geoinf., vol. 8, no. 3, pp. 173-187, 2006. 
[22] B. Bellón, A. Bégué, D. Lo Seen, C. A. de Almeida, and M. Simões, “A remote sensing approach for regional-scale mapping of agricultural land-use systems based on NDVI time series," Remote Sens., vol. 9, no. 6, pp. 1-17, 2017.

[23] G. M. Foody, D. S. Boyd, and M. E. J. Cutler, "Predictive relations of tropical forest biomass from Landsat TM data and their transferability between regions," Remote Sens. Environ., vol. 85, no. 4, pp. 463-474, 2003.

[24] O. Mutanga, E. Adam, and M. A. Cho, "High density biomass estimation for wetland vegetation using worldview-2 imagery and random forest regression algorithm," Int. J. Appl. Earth Obs. Geoinf., vol. 18, no. 1, pp. 399-406, 2012.

[25] E. P. Huete, A. R, Glenn, Remote Sensing of Ecosystem Structure and Function, Advance in Environtment Remote Sensing. Boca Raton: CRC Press, 2011.

[26] H. J. . Waas and B. Nababan, "Pemetaan dan Analisis Index Vegetasi Mangrove di Pulau Saparua, Maluku Tengah," E-Jurnal Ilmu dan Teknol. Kelaut. Trop., vol. 2, no. 1, pp. 5058,2010 . 